\title{
Towards better understanding of vegetable market functioning: the Lithuanian cases of fresh tomatoes and cucumbers
}

by Jurkénaité, N. and Paparas, D.

Copyright, publisher and additional information: This is the authors accepted manuscript. The final published version (version of record) is available online via Sage

Please refer to any applicable terms of use of the publisher.

DOI: https://doi.org/10.1177/0030727019866208

Jurkénaité, N. and Paparas, D. 2019. Towards better understanding of vegetable market functioning: the Lithuanian cases of fresh tomatoes and cucumbers. Outlook on Agriculture. 


\section{Towards better understanding of vegetable market functioning: the Lithuanian cases of fresh tomatoes and cucumbers}

\begin{tabular}{|c|l|}
\hline Journal: & Outlook on Agriculture \\
\hline Manuscript ID & OAG-19-0166 \\
\hline Menuscript Type: & Original Research Article \\
\hline Keywords: & Agriculture, price transmission, supply chain, asymmetry, policy \\
\hline Abstract: & $\begin{array}{l}\text { The efficiency of the EU vegetable market depends on the ability of } \\
\text { member states to identify and solve market functioning problems of } \\
\text { particular agricultural commodities. The objective is to investigate the } \\
\text { vertical price transmission along the fresh tomato and cucumber supply } \\
\text { chains in Lithuania. The study reports about the role of the Lithuanian } \\
\text { domato and cucumber production in the EU context and discusses main } \\
\text { analysis show the presence of the long-run asymmetry within the } \\
\text { studied value chains suggesting that the markets are not efficient; } \\
\text { however, the market of cucumbers returns to an equilibrium quicker. } \\
\text { Finally, the study confirms that in both cases there are long-term } \\
\text { relationships between retail and farm prices, while the causality is } \\
\text { running from farm to retail level in both markets. }\end{array}$ \\
\hline
\end{tabular}

\section{SCHOLARONE Manuscripts}




\section{Towards better understanding of vegetable market functioning: the Lithuanian} 2 cases of fresh tomatoes and cucumbers

\section{Abstract}

The efficiency of the EU vegetable market depends on the ability of member states to identify and solve market functioning problems of particular agricultural commodities. The objective is to investigate the vertical price transmission along the fresh tomato and cucumber supply chains in Lithuania. The study reports about the role of the Lithuanian tomato and cucumber production in the EU context and discusses main determinants of the current situation. Results of price transmission analysis show the presence of the long-run asymmetry within the studied value chains suggesting that the markets are not efficient; however, the market of cucumbers returns to an equilibrium quicker. Finally, the study confirms that in both cases there are long-term relationships between retail and farm prices, while the causality is running from farm to retail level in both markets.

\section{Keywords}

Agriculture, price transmission, market, vegetable

17

\section{Introduction}

Over the last decade, the focus on the vulnerable position of farmers and consumers became a fruitful research niche for many academics, whereas the latest renaissance of the price transmission topic was driven by 2007/2008 and 2010/2011 price spikes when the issue of fair pricing came to the political arena as an important element of welfare of the certain society groups. The widely discussed topics, shedding light on this problem, became price transmission and the phenomenon of asymmetry, which challenged a well-established traditional concept of the markup pricing along the supply chain.

Most of the academic studies on price transmission in agriculture could be classified in accordance with their research direction or even combine couple overlapping research purposes. The largest share of publications introduces the empirical research on price transmission and confirms market failures or the efficient functioning of supply chains applying different methodologies (Aguiar and Santana, 2002; Ahmed, 2018; Ait Sidhoum and Serra, 2016; Bakucs et al., 2007; Girapunthong et al., 2003; Jeder et al., 2017; Munyeka, 2014; Myae at el., 2006; Rezitis and Pachis, 2013, 2016). An important research direction includes explanatory studies. Main factors determining the deviation from the markup concept and undesired price behaviour are discussed by Bakucs et al. (2014), Bunte and Peerlings (2003), Pérez Mesa and Galdeano Gómez (2011), Santeramo and Von Cramon-Taubadel (2016), Ward (1982), and etc. Another research direction focuses on the generalisation of the previous theoretical and methodological developments or empirical research findings in order to analyse the advantages or disadvantages of the applied models or methodologies, map differences or similarities of agricultural commodity markets (Frey and Manera, 2007; Listorti and Esposti, 2012; Von Cramon-Taubadel, 2017). These studies contribute to the scientific discourse showing state-of-the-art of the research on price transmission and identifying prospective research directions. Finally, the most important research direction is dedicated to the development of theoretical models or techniques estimating important aspects of price transmission and market efficiency. These studies identify crucial estimation problems and improve the knowledge about the price transmission phenomenon (e.g., Parrott et al., 2001).

The aforementioned studies on fresh tomato and cucumber price behaviour provide contradicting results and allow to state that the case of every country is a valuable contribution to a better understanding of vegetable market failures. Therefore, this paper provides a contribution to the first 
45 group of studies and improves the knowledge about the functioning of the EU vegetable market 46 47 were omitted due to missing long-term price series.

The objective of the paper is to investigate the vertical price transmission along the fresh tomato and cucumber supply chains in Lithuania. The research question is set as follows: Does vertical price transmission of the Lithuanian fresh tomatoes and cucumbers have an impact on market efficiency?

The paper provides additional arguments for the discourse on the price transmission phenomenon adding the Lithuanian case. This study fills the gap in the scarce research on price changes along the cucumber supply chain, contributes to the better understanding of the EU vegetable market functioning. Findings confirm the need of the further in-depth research and provide additional arguments for policy makers mapping market functioning problems, which could result in welfare losses on farm or retail levels.

\section{Research on vertical price transmission among tomato and cucumber supply chains}

One of the most recognisable publications on price transmission in the vegetable market belongs to Ward (1982) who investigated the relationships of vegetable prices, including cucumbers and tomatoes, between shipping point, wholesaler, and retailer levels in the USA and found both symmetric and asymmetric behaviour. The study argued that the traditional price markup concept often failed to explain the behaviour of prices along the supply chain of the analysed vegetables, and Ward (1982) assumed that perishability could be an important factor contributing to asymmetric price transmission.

Few decades later, the similar study of the USA tomato prices was conducted by Girapunthong et al. (2003), however, most of the findings contradicted to the previous results, and researchers assumed that the role of perishability had reduced due to important structural changes improving both post-harvest storage and supply chain management practices. The evidence of the one-way causality and the leadership of producer prices were found, while Ward (1982) identified wholesalers as the main pricing node. Retail prices reacted to the growth of wholesale prices faster than to fall, while conclusions of Ward (1982) were contrary. At the same time, the later study showed that the behaviour of prices on producer-retail level was symmetric. Parrott et al. (2001) also investigated the USA case of tomatoes and found no evidence of market inefficiencies between shipping point and retail levels.

Later, Santeramo and Von Cramon-Taubadel (2016) investigated the link between the asymmetric price behaviour and perishability in Italy. They looked for the long- and short-run price adjustments and concluded that for more perishable products, including tomatoes, price transmission was symmetric.

The issues of the long-run price transmission and volatility in the Spanish tomato supply chain were analysed by Ait Sidhoum and Serra (2016). They found an evidence of the long-run relationship between prices and slow adjustment of retail prices to the equilibrium assuming that the situation could be explained by market power at the downstream level.

Aguiar and Santana (2002) investigated the impact of market concentration and perishability on the asymmetric price behaviour and concluded that in case of the Brazilian tomato market both factors were less important than inflation, which empowered even actors without market power to transmit price increases faster than decreases. The asymmetric price behaviour and the causality from farm to retail were found.

Bunte and Peerlings (2003) investigated the short-run price transmission effects on welfare of stakeholders along the Dutch cucumber supply chain. Findings suggested that changes of market power and supply shocks on oligopoly and oligopsony markets influenced the asymmetric behaviour and determined the welfare of stakeholders. 
1

The similar methodological framework was employed to investigate the effects of the short- and long-run price transmission in Hungary (Bakucs et al., 2007), Limpopo Province (Munyeka, 2014), and Tunisia (Jeder et al., 2017). Results showed that in case of Hungary and Tunisia prices were determined on the level of the downstream market, while in Limpopo Province the market power was on farm level. The long-run asymmetric behaviour was found as a common feature of the analysed chains, but the short-run price transmission in Limpopo Province was symmetric.

The long- and short-run effects of price changes among the Greek tomato (Rezitis and Pachis, 2013, 2016) and cucumber (Rezitis and Pachis, 2016) supply chains were investigated applying different states of price volatility. According to studies, the behaviour of prices along the chains of cucumbers and tomatoes differed significantly, and findings questioned the impact of the Common Market Organization on the domestic supply chains of different fruits and vegetables in EU member states. The tomato market under the low volatility regime was efficient, while in the state of high volatility behaved asymmetrically, and the retail price led the producer price in the long-term period. The cucumber supply chain demonstrated a symmetric behaviour and the feedback between retailer and producer prices both in the short- and long-run in the high volatility state, while the asymmetric behaviour and the influence of producer prices on the consumer price level in the long run characterised the state of the low volatility.

Ahmed (2018) investigated the Egyptian fresh tomato supply chain and found that price increases were transmitted better than decreases on both producer-wholesaler and wholesaler-retailer levels. Results suggested that the retail sector exercised a market power contributing to the asymmetric price behaviour and transmitting price increases more fully than decreases.

To conclude, the conducted empirical studies on vertical price transmission along fresh tomato and cucumber supply chains covered a wide geographic area and focused on different supply chain stakeholders, data quality and frequency, research periods and econometric techniques. However, these empirical studies did not make a coherent and clear picture with complementary findings, but rather confirmed the importance of the individual case studies for the better understanding of the vegetable market functioning.

\section{Development of tomato and cucumber production}

The paper introduces the situation of the Lithuanian tomato and cucumber production and the role of this agricultural production in the EU context, focuses on the analysis of vertical price transmission of fresh tomatoes and cucumbers in the Lithuanian market. The analysis of changes in tomato and cucumber production relies on data collected on November 23, 2018, from online databases of Statistics Lithuania and Eurostat.

Tomatoes play a significant role in the EU agriculture and this vegetable is included in a daily ration of many EU citizens. According to Eurostat, in 2017, tomatoes covered 241.3 thousand hectares (ha) of the EU harvested area, and production accounted for 17,426.6 thousand tonnes. The EU area occupied by tomatoes decreased by $7.0 \%$ in the year 2017 as compared to 2010 , while the harvested production increased by $18.2 \%$.

Cucumber production in the EU agriculture was less important, but the development trends were similar. According to Eurostat, this vegetable covered 31.9 thousand ha of the EU harvested area in 2017, and the corresponding loss of area was $12.4 \%$, compared to the year 2010. In 2017 , the production amounted to 2,301.2 thousand tonnes, however, this indicator showed an increase of $9.8 \%$ over the period analysed.

Table 1 illustrates the contribution of Lithuanian tomato and cucumber production to the EU agriculture. According to Eurostat, the average yields of these vegetables in top five producing countries and Lithuania differ significantly. Furthermore, the average yields of these vegetables for EU 
member states were growing over the last decade. The yield situation and competitive advantages of EU member states depended on many factors. Climate issues, farming structure and ability to invest in improved vegetable varieties, greenhouse production, supplemental lighting and heating, targeted use of nutrients and water were among the most important aspects of success.

Table 1. Top five tomato and cucumber producing countries in the EU and Lithuania in 2017

\begin{tabular}{clcl}
\hline Rank & \multicolumn{1}{c}{ Area (\%) } & Rank & \multicolumn{1}{c}{$\begin{array}{c}\text { Harvested } \\
\text { production (\%) }\end{array}$} \\
\hline \multicolumn{4}{c}{ Tomatoes } \\
\hline 1 & Italy (38.40) & 1 & Italy (31.98) \\
\hline 2 & Spain (25.22) & 2 & Spain (29.63) \\
\hline 3 & Slovenia (9.20) & 3 & Portugal (10.03) \\
\hline 4 & Portugal (8.65) & 4 & Netherlands (5.22) \\
\hline 5 & Greece (5.52) & 5 & Poland (5.15) \\
\hline 12 & Lithuania (0.23) & 20 & Lithuania (0.07) \\
\hline \multicolumn{4}{c}{ Cucumbers } \\
\hline 1 & Poland (28.80) & 1 & Spain (27.57) \\
\hline 2 & Spain (23.44) & 2 & Poland (19.6) \\
\hline 3 & Romania (17.05) & 3 & Netherlands (17.39) \\
\hline 4 & Greece (5.89) & 4 & France (6.66) \\
\hline 5 & Italy (5.61) & 5 & Greece (5.15) \\
\hline 7 & Lithuania (3.38) & 16 & Lithuania (0.81) \\
\hline
\end{tabular}

Source: own elaboration on the basis of Eurostat data (2018-11-23).

Lithuanian tomatoes and cucumbers are mainly produced on farmer and family farms with a dominant share of outdoor planting, while agricultural companies and enterprises, characterised by higher yields, occupy less than $3.0 \%$ of the harvested area. According to Statistics Lithuania, the comparison of the harvested area for the period 2010-2017 allows identifying the remarkable shrinking of the tomato production area from 0.7 to 0.6 thousand ha and the cucumber production area from 1.6 to 1.2 thousand ha.

It is important to note that only $11.2 \%$ of Lithuanian tomatoes were planted under glass or high accessible cover in 2017, while for cucumbers the share of such production accounted for $49.8 \%$. During the period from 2010 to 2017, a slight decrease of tomato production under glass and highly accessible cover is noticeable. On the contrary, the cucumber indoor production demonstrated a small increase. This feature of Lithuanian tomato and cucumber production is one of the most important explaining low yields.

A significant gap is observable comparing average yield and average outdoor yield. In 2017, these figures for tomatoes were 212.1 and $98.5 \mathrm{~kg}$ per ha respectively, while for cucumbers -160.5 and 65.9 $\mathrm{kg}$ per ha. The modest share of agricultural companies and enterprises demonstrated higher average yields than farmer and family farms, because they were able to invest in glasshouse cultivation and scientific innovations.

\section{Material and methods}

\section{Research data}

The study of price transmission is based on the average retail and commercial farm prices for the period from 2010 to 2017 (Figure 1). The data from the SE 'Agricultural Information and Rural Business Centre' was used. 
Cucumbers

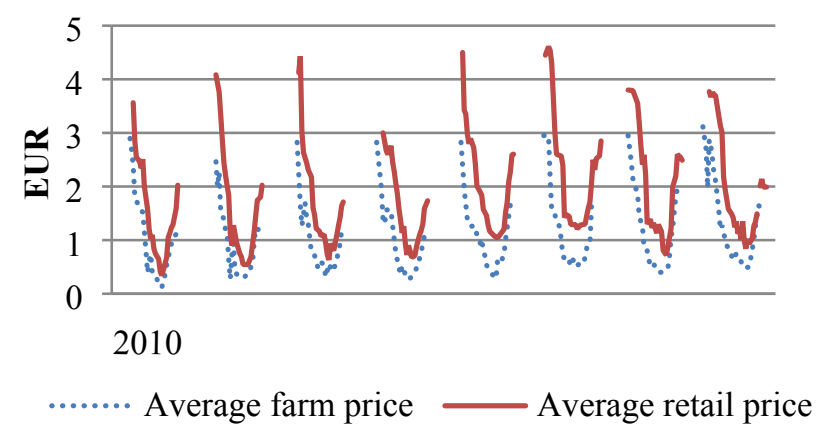

\section{Tomatoes}

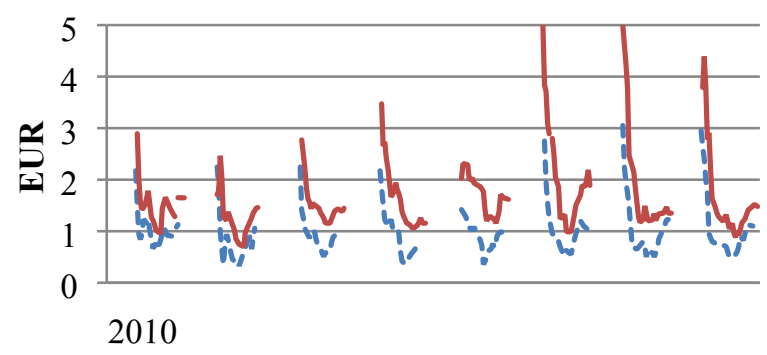

---- Average farm price $\longrightarrow$ Average retail price

Figure 1. Average cucumber and tomato prices: farm and retail levels Source: own elaboration based on data from SE 'Agricultural Information and Rural Business Centre'.

The average retail price covers only fresh tomatoes and fresh short-fruit cucumbers of the Lithuanian origin. The weekly average retail price is derived from the dominant Lithuanian supermarkets in seven counties. Weekly average prices on Lithuanian farms are not collected, and the study relies on the average price, which is calculated from the weekly announced minimum and maximum prices on Lithuanian farms, as a proxy of the average farm price. Unfortunately, the statistics on average farm price is available only on monthly basis; however, for the analysis of fresh vegetables a weekly frequency is more desirable as a higher level of the aggregation corrupts the outlook and hides visibility of the certain processes.

Figure 1 demonstrates that data availability depends on seasons. The beginning of the season for fresh vegetables is characterized by high prices, which decline sharply and demonstrate a slight growth at the end of the season. These price fluctuations could be explained by swelling production costs which compensate unfavourable weather conditions.

Remarkable changes of season duration are observed if we compare availability of fresh tomatoes on farms for the analysed period. Thus, some vegetable farms moved towards the cultivation throughout the year.

\section{Methodological research framework}

The analysis of vertical price transmission is conducted applying a framework of econometric techniques, which explore the relations between farmer and retailer prices. The study uses logarithmic transformations of prices in order to solve typical statistical problems (Brooks, 2008).

First, the Augmented Dickey-Fuller (ADF) test (Dickey and Fuller, 1979) is conducted to classify each price series into stationary and non-stationary. Results of this test help to select appropriate research techniques. The ADF test is run twice: including a constant and selecting a trend specification with an intercept. If the null hypothesis $\left(H_{0}\right)$ of the unit root presence is not approved, price series are stationary. Data stationarity is an important property allowing to avoid spurious regression implementing further steps of the analysis.

Second, the Johansen co-integration test (Johansen 1991; Johansen 1995) is run to verify if farm and retail prices in the selected supply chains move together or demonstrate different development trends in a long run. The Johansen test combines results of Trace and Max-Eigen tests and verifies the $H_{0}$ investigating the presence of the selected number of co-integrated vectors.

Engle and Granger (1987) state that the co-integrated variables mean the presence of the cointegrated vector. If prices on farm and retail levels are stationary and co-integrated, the co-integrated 
vector could be presented as the ECM. An important contribution to the development of this technique was done by Johansen $(1988,1991,1995)$.

Third, the ECM for farm and retail prices is applied (similar to described in Von Cramon-Taubadel (2017)). The equation shows short-term relationships between prices on farm and retail levels and demonstrates the speed of recovery to the general equilibrium in the long-term period. The latter is measured applying error correction term (ECT). The ECT indicates the time of price return to the initial equilibrium. This figure must be negative and statistically significant to ensure the validity of the cointegration.

The next important step is the analysis of the Granger causality (Granger, 1969). The Granger causality test allows exploring the presence of the causality between farmer and retailer and the nature of the price feedback along the supply chain. For the each vegetable two $H_{0}$ are set in order to answer the question whether there is a stakeholder with the leading role in price setting or market functions efficiently.

Finally, the analysis of price transmission symmetry is conducted. Von Cramon-Taubadel (2017) reports on currently applied research in this area and provides some methodological basis. The results of these studies show whether price shocks have an impact on market efficiency. The asymmetric price behaviour means a deviation from the price markup concept and transmission problems along the supply chain.

This study deploys the method of the consistent momentum threshold autoregressive model (MTAR) described by Enders and Siklos (2001). MTAR catches 'possibility of asymmetrically 'sharp' movements' (Enders and Granger, 1998: 304), while the previous threshold autoregressive models empowered the analysis of deep fluctuations.

At the first stage MTAR confirms or rejects the $H_{0}$ of no cointegration between variables. If the presence of the long-term period relation between prices of farmer and retailer is proved, the second $H_{0}$ tests for the presence of symmetry.

\section{Results}

The application of the selected price transmission estimation framework is related to the nature of price series. First, the ADF test results are examined (Table 2).

Table 2. Results of ADF test for cucumber and tomato price series

\begin{tabular}{|c|c|c|c|c|}
\hline \multirow{3}{*}{\multicolumn{2}{|c|}{ Exogenous: Constant }} & \multicolumn{2}{|c|}{$t$-statistic } & \multirow{3}{*}{ Prob } \\
\hline & & \multicolumn{2}{|c|}{ Cucumbers* } & \\
\hline & & LFARMC & LRETAILC & \\
\hline \multicolumn{2}{|c|}{ ADF test statistic } & -5.16 & -4.59 & $0.00^{1}$ \\
\hline \multirow{3}{*}{$\begin{array}{l}\text { Test } \\
\text { critical } \\
\text { values: }\end{array}$} & $1 \%$ level & -3.46 & -3.46 & $0.00^{1}$ \\
\hline & $5 \%$ level & -2.87 & -2.87 & $0.00^{1}$ \\
\hline & $10 \%$ level & -2.57 & -2.57 & $0.00^{1}$ \\
\hline \multicolumn{2}{|c|}{$\begin{array}{l}\text { Trend specification: } \\
\text { intercept only }\end{array}$} & LFARMC & LRETAILC & \\
\hline \multicolumn{2}{|c|}{ ADF test statistic } & -5.53 & -5.09 & $<0.01^{2}$ \\
\hline \multirow{3}{*}{$\begin{array}{l}\text { Test } \\
\text { critical } \\
\text { values: }\end{array}$} & $1 \%$ level & -4.95 & -4.95 & $<0.01^{2}$ \\
\hline & $5 \%$ level & -4.44 & -4.44 & $<0.01^{2}$ \\
\hline & $10 \%$ level & -4.19 & -4.19 & $<0.01^{2}$ \\
\hline \multirow{2}{*}{\multicolumn{2}{|c|}{ Exogenous: Constant }} & \multicolumn{2}{|c|}{ Tomatoes** } & \\
\hline & & LFARMT & LRETAILT & \\
\hline \multicolumn{2}{|c|}{ ADF test statistic } & -7.50 & -7.18 & $0.00^{1}$ \\
\hline \multirow{2}{*}{$\begin{array}{l}\text { Test } \\
\text { critical }\end{array}$} & $1 \%$ level & -3.46 & -3.46 & $0.00^{1}$ \\
\hline & $5 \%$ level & -2.87 & -2.87 & $0.00^{1}$ \\
\hline
\end{tabular}




\begin{tabular}{lcccc}
\hline values: & $10 \%$ level & -2.57 & -2.57 & $0.00^{1}$ \\
\hline $\begin{array}{l}\text { Trend specification: } \\
\text { intercept only }\end{array}$ & LFARMT & D(LRETAILT) & \\
\hline ADF test statistic & -7.96 & -13.96 & $<0.01^{2}$ \\
\hline Test & $1 \%$ level & -4.95 & -4.95 & $<0.01^{2}$ \\
\cline { 2 - 5 } critical & $5 \%$ level & -4.44 & -4.44 & $<0.01^{2}$ \\
\cline { 2 - 4 } values: & $10 \%$ level & -4.194 & -4.19 & $<0.01^{2}$ \\
\hline 1 MacKinnon (1996) one-sided $p$-values. & \\
2 Vogelsang (1993) asymptotic one-sided p-values. & \\
* Lag Length: 1 (Automatic (SIC), maxlag = 15). & \\
** Lag Length: 0 (Automatic (SIC), maxlag=14). & \\
Source: own elaboration.
\end{tabular}

Results confirm that in case of the exogenous constant the $H_{0}$ of unit root presence could be rejected for farm and retail price series in both tomato and cucumber supply chains, because the absolute values of the ADF test statistic are higher than test critical values, while results are significant at $1.0 \%$ level.

The ADF test with trend specification, which includes only the intercept, also rejects the $H_{0}$, however, the retail price series of tomatoes become stationary only in first differences. Thus, farm and retail price series are stationary and the further analysis will not result in spurious regressions.

Empirical results show that in both examined markets of tomatoes and cucumbers all tested variables have been identified as stationary in the first difference. Prices are integrated of first order. Thus, the tests use the first difference to ensure that the findings are valid as seasonality does not affect the time series and also assist in prevention of the spurious regression.

The next step verifies the presence of relations between prices in both supply chains in the long run (Table 3). The Johansen co-integration test under linear deterministic trend shows that for both vegetables the first $H_{0}$ (no co-integration between farm and retail prices in first differences) is rejected. These results are supported by Trace and Max-Eigen statistic values, which are higher than critical values. The $p$-values confirm that results are significant at $1.0 \%$ level.

According to Trace and Max-Eigen tests, the second $H_{0}$ (there is at least 1 co-integrating vector between farm and retail prices in first differences) is also rejected. The results of the Johansen cointegration tests confirm the presence of 2 co-integrating vectors at $1.0 \%$ significance level.

Table 3. Results of the Johansen test for cucumber and tomato prices

\begin{tabular}{|c|c|c|c|c|}
\hline \multirow{6}{*}{ 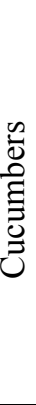 } & $\begin{array}{l}\text { Hypothesized } \\
\text { No of } \\
\text { cointegrations }\end{array}$ & Eigenvalue & $\begin{array}{l}\text { Trace } \\
\text { Statistic }\end{array}$ & $\begin{array}{l}\text { Critical } \\
\text { Value } \\
(0.05) \\
\end{array}$ \\
\hline & None * & 0.29 & 97.48 & 15.49 \\
\hline & At most $1^{*}$ & 0.09 & 21.39 & 3.84 \\
\hline & $\begin{array}{l}\text { Hypothesized } \\
\text { No. of } \\
\text { cointegrations }\end{array}$ & $\begin{array}{l}\text { Max-Eigen } \\
\text { Statistic }\end{array}$ & $\begin{array}{l}\text { Critical } \\
\text { Value } \\
(0.05)\end{array}$ & Prob** \\
\hline & None * & 76.09 & 14.26 & 0.00 \\
\hline & At most $1 *$ & 21.39 & 3.84 & 0.00 \\
\hline \multirow{5}{*}{ 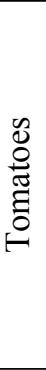 } & $\begin{array}{l}\text { Hypothesized } \\
\text { No. of } \\
\text { cointegrations }\end{array}$ & Eigenvalue & $\begin{array}{c}\text { Trace } \\
\text { Statistic }\end{array}$ & $\begin{array}{l}\text { Critical } \\
\text { Value } \\
(0.05)\end{array}$ \\
\hline & None * & 0.31 & 112.35 & 15.49 \\
\hline & At most $1^{*}$ & 0.17 & 37.87 & 3.84 \\
\hline & $\begin{array}{l}\text { Hypothesized } \\
\text { No. of } \\
\text { cointegrations } \\
\end{array}$ & $\begin{array}{l}\text { Max-Eigen } \\
\text { Statistic }\end{array}$ & $\begin{array}{l}\text { Critical } \\
\text { Value } \\
(0.05) \\
\end{array}$ & Prob** \\
\hline & None * & 74.48 & 14.26 & 0.00 \\
\hline
\end{tabular}


At most 1 *

37.87

3.84 0.00

$* H_{0}$ is rejected.

**MacKinnon-Haug-Michelis (1999) $p$-values.

Lags interval (in first differences): 1 to 1 .

Source: own elaboration.

The ECM estimates the speed of adjustment of prices to the new long-run equilibrium. The ECM results for cucumbers and tomatoes are provided in Table 4.

Table 4. ECMs for cucumbers and tomatoes

\begin{tabular}{lc|lc}
\hline \multicolumn{2}{c|}{ Cucumbers } & \multicolumn{2}{c}{ Tomatoes } \\
\hline \multicolumn{2}{c}{ Cointegrating eqation 1 } & \multicolumn{2}{c}{ Cointegrating eqation 2 } \\
\hline LRETAILC(-1) & 1.00 & LRETAILT(-1) & 1.00 \\
\hline LFARMC(-1) & -0.80 & LFARMT(-1) & -0.47 \\
& $(0.03)$ & & $(0.07)$ \\
& {$[-29.73]$} & & {$[-6.59]$} \\
\hline D2013(-1) & -0.11 & D2011(-1) & -0.08 \\
& $(0.03)$ & & $(0.07)$ \\
& {$[-3.44]$} & & {$[-1.06]$} \\
\hline C & -0.56 & C & -0.40 \\
\hline Error Correction: & & Error Correction: & \\
D(LRETAILC) & & D(LRETAILT) & \\
\hline ECT & -0.47 & ECT & -0.24 \\
& $(0.06)$ & & $0.04)$ \\
& {$[-8.02]$} & & {$[-6.18]$} \\
\hline
\end{tabular}

Source: own elaboration.

According to the results in Table 4, in the equation for cucumbers, the ECT amounts to -0.47 . The figure is both negative and statistically significant. This means that $47.1 \%$ of the disequilibrium remains dissipated before the start of the next period. The absolute value of $t$-statistic (-8.0) is higher than critical. Thus, results are statistically significant and the equation for cucumbers is valid. The ECT for tomatoes is negative and statistically significant, it amounts to -0.24 . This means that the retailer price will recover at the speed of $24.4 \%$. The value of $t$-statistic $(-6.2)$ for tomatoes is statistically significant.

Furthermore, it should be noted that the adjustment speed for tomatoes is $24.4 \%$, while for cucumber $-47.1 \%$. This means that the speed of market recovery towards equilibrium after a shock has occurred differs almost twice, and the market of cucumbers recovers to the long-run equilibrium faster.

The pairwise Granger causality tests allow to analyse whether the farm price in the short run helps to predict the retail price, and vice versa. Hence, for the each of the selected vegetables we investigate two $H_{0}$ (Table 5).

Table 5. The Granger causality test for cucumber and tomato prices (2 lags)

\begin{tabular}{clcc}
\hline \multicolumn{1}{c}{ The investigated $H_{0}$} & F-Statistic & Prob. \\
\hline \multirow{2}{*}{ Cucumbers } & $\begin{array}{l}\text { LFARMC does not } \\
\text { Granger cause }\end{array}$ & $93.18^{*}$ & 0.00 \\
\cline { 2 - 4 } & $\begin{array}{l}\text { LRETAILC } \\
\text { LRETAILC does not } \\
\text { Granger cause }\end{array}$ & 0.74 & 0.48 \\
LFARMC & & \\
\hline \multirow{2}{*}{ Tomatoes } & $\begin{array}{l}\text { LRETAILT does not } \\
\text { Granger cause } \\
\text { LFARMT }\end{array}$ & 0.04 & 0.96 \\
\hline
\end{tabular}


$* H_{0}$ is rejected.

Source: own elaboration.

Results show the same causality direction for tomato and cucumber supply chains. In case of cucumbers we cannot reject the $H_{0}$ that farm prices do not cause retail prices. As a result, we can see one-way direction of the Granger causality from farm to retail.

In the Lithuanian tomato market the same behaviour of prices as in cucumber market is observed. The $H_{0}$ that farm prices does not Granger cause retail prices cannot be rejected. This market also has one-way causality and a stakeholder leading prices in the short term period. In case of tomatoes prices go from farm to retail level too.

At the final stage of our analysis, the possibility of asymmetric linkages between the each price pair in the long run time horizon is examined. Firstly, we examine whether the co-integration and asymmetry exist.

Table 6 presents the empirical results that obtained from the MTAR model. The $H_{0}$ of no cointegration $\left(H_{0}: \rho 1=\rho 2=0\right)$ is rejected for all price pairs (tomatoes and cucumbers) as the $F$-joint values amount to 6.8 and 13.9 respectively. The results evidence stable long run relationships between the examined agricultural commodities and suggest that the markets of farmers and retailers are indeed cointegrated.

Table 6. Results of MTAR model for cucumber and tomato prices

\begin{tabular}{lcccc}
\hline & \multicolumn{2}{c}{ Cucumbers } & \multicolumn{2}{c}{ Tomatoes } \\
\hline $\begin{array}{l}\text { Above } \\
\text { threshold }\end{array}$ & -0.36 & 0.10 & -0.14 & 0.07 \\
\hline $\begin{array}{l}\text { Below } \\
\text { threshold }\end{array}$ & -0.08 & 0.10 & -0.34 & 0.06 \\
\hline $\begin{array}{l}\text { Threshold } \\
\text { Value }\end{array}$ & 0.00 & & 0.00 & \\
\hline$F$-equal & 5.92 & $(2.79)^{*}$ & 4.78 & $(3.70)^{*}$ \\
\hline $\begin{array}{l}T \text {-max } \\
\text { value }\end{array}$ & -0.83 & $(-2.14)^{*}$ & -2.00 & $(-1.99)^{*}$ \\
\hline $\begin{array}{l}F \text {-joint } \\
\text { (phi) }\end{array}$ & 6.77 & $(5.87)^{*}$ & 13.93 & $(6.46)^{*}$ \\
\hline S-urcent & & & &
\end{tabular}

Source: own elaboration

Since the co-integration exists, we therefore test for asymmetry. Results indicate that the $H_{0}$ of symmetry $\left(H_{0}: \rho 1=\rho 2\right)$ is rejected in all price pairs as the $F$-equal values are 5.9 and 4.8 respectively. Price transmission - in the long run - appears to be asymmetric since negative shocks are transmitted with higher intensity than positive-type shocks. Thus, the examined markets cannot be characterized as efficient.

\section{Discussion}

According to the results of the price transmission analysis, the Lithuanian fresh tomato and cucumber markets suffer from market efficiency problems. The Granger causality test identified oneway causality direction from farmer to retailer in the analysed Lithuanian markets. Girapunthong et al. (2003) and Munyeka (2014) also found similar results supporting one-way causality from upstream levels, while Jeder et al. (2017) concluded that the direction was from retail to farm level. 
The results contradict to Rezitis and Pachis (2013) findings showing two-way causality in tomato supply chain. It should be noted that the later research conducted by Rezitis and Pachis (2016) evidences that the results of the Granger causality test could differ under different volatility regimes and switch from two-way to one-way direction. As a result, the selected methodological framework and data could lead to different outcomes.

The Granger causality test cannot be used for the prediction of the price development in the future, but the findings explain short-run relations between prices in the past. In the Lithuanian tomato and cucumber markets, the price leadership is on producer level. Thus, the welfare of farmers is not discriminated.

The study of price transmission, employing MTAR model, also evidences in favour of the inefficient functioning of tomato and cucumber markets in the long run. These results contradict to the findings of Parrott et al. (2001) and Gaetano Santeramo and Von Cramon-Traubel (2016) who found no confirmation of asymmetric behaviour in the USA and Italian tomato markets. However, the Lithuanian case of asymmetric price transmission in tomato market is not unique and corresponds to the findings of researchers in Hungary (Bakucs et al., 2007), Tunisia (Jeder et al., 2017), the USA (Ward, 1982), Egypt (Ahmed, 2018), Brazil (Aguiar and Santana, 2002), and etc.

According to the previous studies, some countries combine both symmetric and asymmetric price behaviour. The results depend on the selected for the analysis stakeholders' level (Girapunthong et al., 2003; Munyeka, 2014; Rezitis and Pachis, 2016) or price transmission research horizon (Rezitis and Pachis, 2016). The conducted studies evidence both negative and positive asymmetry (Ahmed, 2018; Girapunthong et al., 2003; Rezitis and Pachis, 2016; Ward, 1982) and provide limited possibility to make a coherent picture of the phenomenon. Thus, the feature of perishability cannot be a main explanatory factor for asymmetric price behaviour and other characteristics of the particular markets are important.

The presentation of the typical research results (for the similar markets, supply chain levels or countries) is complicated. For example, Rezitis and Pachis (2016) show that cucumber and tomato price behaviour depends on the volatility regime. In the short- and long-run, the regime-dependent response of the selected stakeholders in the same country could demonstrate both symmetric and asymmetric behaviour. The aforementioned results confirm the importance of the flexible legislation framework for the Common Agricultural Policy allowing to react to the diversity of market problems in the EU member states.

The generalisation of the previous studies allows identifying the desired directions for the further research. First, the analysis could include more supply chain levels in order to study the relations between different stakeholders and identify the intermediary responsible for the inefficient price behaviour. Second, study conducted by Rezitis and Pachis (2016) shows that the results could depend on the selected regime. The regime-dependent study could also provide important findings for the policy makers and help to improve the functioning of the market. However, it is important to note that the price situation is often determined by both internal and external trade policies (Anderson, 2009).

\section{Conclusion}

In Lithuania, the production of tomatoes and cucumbers is shrinking. Although this type of farming is supported by the Common Agricultural Policy, unfavourable climate conditions combined with the farm structure make domestic production less competitive in the EU market. The current support (direct payments and market measures) could be accompanied by additional investments in glasshouses and combined with the production-specific knowledge transfer allowing to increase yields.

The investigation of vertical price transmission shows possible market efficiency drawbacks. Although a long-term horizon relationship between the examined prices in both markets was found, the 
1

results report about different recovery speed to the long run equilibrium. The ECT for tomatoes is 0.24 , while for cucumbers - -0.47 . This finding shows that the market of cucumbers recovers to the equilibrium faster than tomato market and gives a signal for scientists to conduct a more detail research explaining the main determinants of such price behaviour.

Study also finds the evidence of the asymmetric price behaviour in tomato and cucumber markets, because negative shocks are transmitted better than positive. Asymmetric price transmission might have significant effects on the distribution of welfare and policy implementation. As asymmetry was found to be present within the examined markets of tomatoes and cucumbers for the period studied it shows that the current legislation is ineffective to ensure a perfectly competitive market.

Outcomes of the Granger causality test show the similar causality direction for tomato and cucumber supply chains. In case of tomatoes and cucumbers we can see one-way direction of the Granger causality from farm to retail. Thus, the direction is favourable for the welfare of farmers as they can impact price development on the market in the short run.

\section{References}

Aguiar D and Santana J (2002) Asymmetry in Farm to Retail Price Transmission: Evidence from Brazil. Agribusiness 18: 37-48.

Ahmed O (2018) Vertical price transmission in the Egyptian tomato sector after the Arab Spring. Applied Economics 50: 5094-5109.

Ait Sidhoum A and Serra T (2016) Volatility Spillovers in the Spanish Food Marketing Chain: The Case of Tomato. Agribusiness 32: 45-63.

Anderson K (2009) Five Decades of Distortions to Agricultural Incentives. In: Anderson K (ed) Distortions to agricultural incentives: a global perspective, 1955-2007. The International Bank for Reconstruction and Development / The World Bank, pp. 3-64.

Bakucs LZ, Fertő I and Szabó GG (2007) Price transmission in the Hungarian vegetable sector. Studies in Agricultural Economics 106: 23-40.

Bakucs Z, Fałkowski J and Fertõ I (2014) Does Market Structure Influence Price transmission in the Agro-food Sector? A Metha-analysis Perspective. Journal of Agricultural Economics 65(1): 1-25.

Brooks C (2008) Introductory Econometrics for Finance. New York: Cambridge University Press.

Bunte $\mathrm{F}$ and Peerlings $\mathrm{J}$ (2003) Asymmetric price transmission due to market power in the case of supply shocks. Agribusiness 19: 19-28.

Dickey DA and Fuller WA (1979) Distribution of the Estimators for Autoregressive Time Series with a Unit Root. Journal of the American Statistical Association 74(366): 427-431.

Enders W and Siklos PL (2001) Cointegration and Threshold Adjustment. Journal of Business \& Economic Statistics 19(2): 166-176.

Engle RF and Granger CWJ (1987) Co-Integration and Error Correction: Representation, Estimation, and Testing. Econometrica 55(2): 251-276.

Enders W and Granger CWJ (1998) Unit-Root Tests and Asymmetric Adjustment with an Example Using the Term Structure of Interest Rates. Journal of Business \& Economic Statistics 16(3): 304-311.

Frey G and Manera M (2007) Econometric Models of Asymmetric Price Transmission. Journal of Economic Surveys 21(2): 349-415.

Girapunthong N, VanSickle J and Renwick A (2003) Price Asymmetry in the United States Fresh Tomato Market. Journal of Food Distribution Research 34: 51-59.

Granger CWJ (1969) Investigating Causal Relations by Econometric Models and Cross-spectral Methods. Econometrica 37(3), 424-438.

Jeder H, Naimi A and Oueslati A (2017): Transmission between Retail and Producer Prices for Main Vegetable Crops in Tunisia. International Journal of Food and Agricultural Economics 5: 19-28.

Johansen S (1988) Statistical analysis of cointegration vectors. Journal of Economic Dynamics and Controls 12(2-3): 231-254. 
Johansen S (1991) Estimation and Hypothesis Testing of Cointegration Vectors in Gaussian Vector Autoregressive Models. Econometrica 59(6): 1551-1580.

Johansen S (1995) Likelihood-Based Inference in Cointegrated Vector Autoregressive Models. New York: Oxford University Press Inc.

Listorti G and Esposti R (2012) Horizontal Price Transmission in Agricultural Markets: Fundamental Concepts and Open Empirical Issues. Bio-based and Applied Economics 1(1): 81-108.

Myae AC et al. (2006) The study of Price Behavior of Vegetable Markets in Myanmar and Japan. Journal of the Faculty of the Agriculture - Kyushu University (Japan) 51(1): 139-146.

Munyeka W (2014) Price Mediation in Tomato Commerce of Limpopo Province of the Republic of South Africa. Mediterrean Journal of Social Sciences 5: 778-791.

Parrott S, Eastwood D and Brooker J (2001) Testing for Symmetry in Price Transmission: An extension of Shiller Lag Structure with an Application to Fresh Tomatoes. Journal of Agribusiness 19(1): 35-49.

Pérez Mesa JC and Galdeano Gómez E (2011) Asymmetric Margins in Prices and Retail Supply Chain Integration: the Spanish Vegetable Case. Journal of International Food \& Agribusiness Marketing 22: 211230.

Rezitis A and Pachis D (2013) Investigating the Price Transmission Mechanism of the Greek Fresh Tomato Market with a Markov Switching Vector Error Correction Model. Agricultural Economics Review 14: 29 45.

Rezitis A and Pachis D (2016) Investigating the Price Transmission Mechanisms of Greek Fresh Potatoes, Tomatoes and Cucumbers Markets. Journal of Agricultural \& Food Industrial Organization 14: 91-108.

Santeramo FG and Von Cramon-Traubadel S (2016) On perishability and Vertical Price Transmission: empirical evidences from Italy. Bio-Based and Applied Economics, 5: 199-214.

Von Cramon-Taubadel S (2017) The Analysis of Market Integration and Price Transmission - Results and Implications in an African Context. Agrekon (Agricultural Economics Research, Policy and Practice in Southern Africa) 56: 83-96.

Ward R (1982) Asymmetry in Retail, Wholesale, and Shipping Point Pricing for Fresh Vegetables. American Journal of Agricultural Economics May: 205-212. 
Figure 1. Average cucumber and tomato prices: farm and retail levels Source: own elaboration based on data from SE 'Agricultural Information and Rural Business Centre'.

$85 \times 112 \mathrm{~mm}(96 \times 96 \mathrm{DPI})$
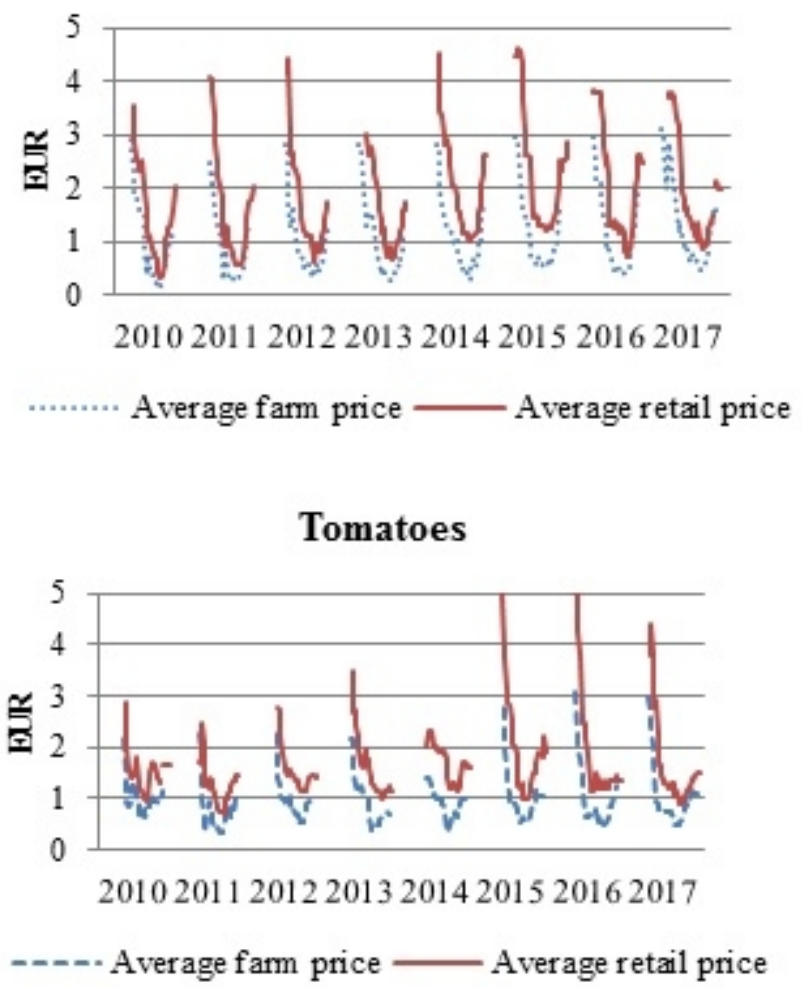

\section{Tomatoes}

